Journal of Educational Research in Developing Areas (JEREDA

Vol. 1. Issue 2, Pp. 100-111, 2020

http://www.jeredajournal.com

E-mail: info@jeredajournal.com

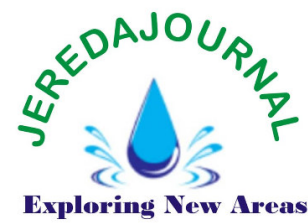

Research Article DOI: https://doi.org/10.47434/JEREDA/ eISSN: $2735-9107$

\title{
BUDGETING / BUDGETARY CONTROL SYSTEM AND INSTITUTIONAL EFFECTIVENESS IN UNIVERSITIES IN KWARA STATE, NIGERIA
}

\section{${ }^{1}$ Folorunsho Muhammed Shuaib, ${ }^{2}$ Anifat Odunola Olanrewaju}

\author{
${ }^{1}$ Kwara State University, Malete. Kwara State, Nigeria \\ ${ }^{2}$ Airforce Institute of Technology, Kaduna, Nigeria \\ 2olanrewajuanifat1@gmail.com \\ Corresponding Author ${ }^{1}$ shuaibfm3@gmail.com \\ (Di) https://orcid.org/0000-0002-4265-9466
}

Received: $13^{\text {th }}$ September, 2020; Revised: $25^{\text {th }}$ September, 2020; Accepted: $29^{\text {th }}$ September, 2020

\section{ABSTRACT}

Introduction: The study examined the relationship between budgeting/budgetary control system and institutional effectiveness in Universities in Kwara State, Nigeria.

Purpose: The purpose of the study was to examine the impact of budget committee, budget implementation, value for money check and internal audit check on institutional effectiveness in universities in Kwara State.

Methodology: Two researchers' questionnaires were designed to collect data from sampled respondents; they were 'Budgeting/Budgetary control System Questionnaire (BBCSQ)' and 'Institutional Effectiveness Questionnaire (IEQ)'. The instruments were validated by two experts to ascertain the content validity while the reliability of the instruments was determined using Cronbach Alpha statistics, thus, the reliability coefficients were found to be 0.83 and 0.76 respectively. Four universities were randomly sampled out of the six accredited universities in Kwara State. The selection represented $67 \%$ of the total population. The respondents were the staff of the bursary department of the sampled universities and 110 respondents were determined out of the 290 targeted population using proportional sampling technique. The data collected were analyzed using SPSS version 21.0 at 0.05 level of significant using PPMC while descriptive statistics of means and standard deviation were used to answer the research questions raised in the study.

Results: The result of the study revealed that there was a significant relationship between budgeting/budgetary control system and institutional effectiveness in Universities in Kwara State $(r$. value $=.578>t$. value $=.000$ ).

Recommendations: It was recommended among others that budget committee should be composed of experienced and well versatile members in the field of accounting and finance to enhance their performance and overall effectiveness in the system.

Keywords: Budgeting, Budgetary Control, Institutional effectiveness, University

\section{Cite paper as:}

Crossref Shuaib, F. M., Olanrewaju, A. O. (2020). Budgeting/budgetary control Cited-by system and institutional effectiveness in universities in Kwara state, Nigeria. Journal of Educational Research in Developing Areas, 1 (2), 100111. https://doi.org/10.47434/JEREDA.1.2.2020.100.

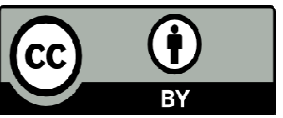

Copyright (c) 2020 The author(s) of this article retain(s) the copyright. 
Journal of Educational Research in Developing Areas (JEREDA

Vol. 1. Issue 2, Pp. 100-111, 2020

http://www.jeredajournal.com

E-mail: info@jeredajournal.com

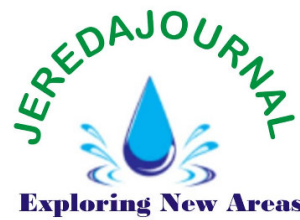

\section{PUBLIC INTEREST STATEMENT}

This study would be of immense significance to management of higher institutions, the bursary \& audit unit, Ministry of Education, institutional agencies: National Universities Commission (NUC), National Commission for Colleges of Education (NCCE) \& National Board for Technical Education (NBTE) because of the relevance of the topic to financial planning and control in the system. References and citations used in the study would be helpful to other researchers on the topic area.

\section{INTRODUCTION}

The effectiveness of any organization depends mainly on the level of management control available in such organization; this therefore cuts across several activities like production, distribution, purchasing, selling and the educational sector as the case may be. However, for effective management of these organizational activities, there must be an efficient and sound management team to handle the control of human, material and financial resources. This means that for the management of these organizations to carry out and achieve its planned activities for the year, there is need to strictly manage and control its spending through a proper adherence to the organization's budget as being prepared by a designated office (or officers). In this regards, Omosidi and Abdulkareem (2012) stated that budget to an institution is one of the principal instruments to which the administrators and management teams of an educational system express their priorities financially for a given period of time. In addition to this, budgeting is described as an accounting device used to plan and control resources of operational departments of governments and other institutions (Abdullahi \& Angus, 2012). In a similar concept, budget was referred to as a comprehensive and coordinated plan that is put together by the management of an organization or establishment; and this plan is always expressed in financial terms for the operations and resources of such establishment within a specific period of time (Lambe, 2014). Therefore, budget has been identified as a key policy instrument for public management of an establishment (Isaac, Lawal \& Okoli, 2015).
In addition to this, university education system needs to prepare budgets for the anticipated revenues and expenditure of the institution. The projected revenues of university are classified into: subventions, internally generated revenue (IGR) from tuition fee; fees from created other IGR Centres; income from other investments; hostel and hotel accommodation management; proceeds from transport services; water production (sachets \& bottled); farming \& poultry work; income from other entrepreneurship \& vocational programmes, administrative charges and other revenue source within the law guiding the institution, grants (local and foreign), incomes from rented properties and others. On the other hand, projected expenditure under the university budgets are usually under personnel cost, recurrent expenditures, administration, and capital expenditures (Malgwi \& Unegbu, 2012). University budgets are prepared to serve as a driving force through which its vision and mission statement could be accomplished within a given period. It also plays important role in the realization of university objectives. It is therefore a known fact that budgeting offers the institution's management the opportunity to examine the details of financial plans for both general situation and the economic interrelationship among all the educational systems of various activities (Omosidi, Oguntunde, Oluwalola \& Ajao, 2019). This is achievable through a suitable framework set up in the university environment and this can be accomplished through the budgetary control system put in place in the system. Warren, Reeve and Duchac (2014), therefore, referred to budget as an accounting device used to plan and control resources of operational departments of Governments and 
Journal of Educational Research in Developing Areas (JEREDA

Vol. 1. Issue 2, Pp. 100-111, 2020

http://www.jeredajournal.com

E-mail: info@jeredajournal.com

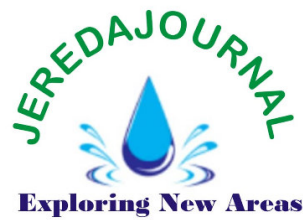

institutions visa viz; Universities, Colleges of Education, Polytechnics and others. To improve the budget performance and implementation in the university environment, there must be a sound budgetary control system which needs to be put in place in order to accomplish the institution's objectives. This can be done by constituting a panel of budget committee and value for money audit committee in the university system to help control the budget spending and also improve the implementation of approved budget figures. Budget implementation is very essential to ensure prudent use of scarce resources based on approved plan.

Accordingly, Omosidi and Oguntunde (2016) affirmed that budget implementation controls the financial behaviour of the institution's administrators because it prevents wasteful spending of funds provided for various educational services or other expenditure heads. Hence, budgetary control system is therefore, a necessity that needs to be put in place for proper financial planning in the university system. According to Chartered Institute of Management Accountants (CIMA, 2008), budgetary control has been referred to as the establishment of a mechanism authorizing responsibilities of executives to the requirements of $a$ policy and the continuous comparison of actual with budgeted results either to secure by individual action the objective of a policy or to provide a basis for its revision.

Moreover, budgetary control system in the university involves a system of management control to which comparison are made between the actual income and expenditures with the budgeted income and expenditures, so that at the end of the fiscal year, the institution can certainly make some decisions whether their plans are being strictly followed, or those plans need to be modified. Therefore, the application of control in any organization or institution coupled with the help of a budget is known as budgetary control (Anohene, 2011).

Volume 1, Number 2

Generally, having prepared the budget, it is the responsibility of the management to ensure that the actual operations are in accordance with the budgeted plans and any variations recorded have to be thoroughly investigated in order to ensure that institutional objectives are achieved in the area of teaching, learning and community service. Specifically, the preparation of a budget in any institution should be the responsibilities of all levels of management and staff, whether strategic, tactical or operational. This will however ensure that the whole system works as a single entity. According to Chukwuma (2013), the preparation of a budget at all levels of government institutions commences by accessing their programmes, ensuring all programmes required are reviewed and making recommendations for new programmes.

However, the kind of budgetary control measures put in place in educational institutions, especially at the universities system will determine the level of its overall performance. Therefore, the impacts of budgetary control on universities effectiveness are as follows:

a. Budgetary control system in university serves as an instrument to track-down the flow of resources in the institution. The control aspect of the budget tries to monitor and ensure that every naira must be judiciously spent to fulfill the budget purpose (Malgwi \& Unegbu, 2012).

b. Budgetary control in an institution will enhance effective performance in the essence of proper control of resources of operational departments and units (Abdullahi \& Angus, 2012).

c. Budgetary control in an institution ensures prudent use of scarce resources. This implies that the budgetary control measure put in place tries to monitor all the activities of the institution and to also ensure that every naira and kobo to be spent must be justified to accomplish the budget 
Journal of Educational Research in Developing Areas (JEREDA

Vol. 1. Issue 2, Pp. 100-111, 2020

http://www.jeredajournal.com

E-mail: info@jeredajournal.com

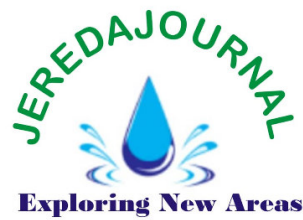

objective (Malgwi \& Unegbu, 2012).

Finally, in view of the relevance of budgeting/budgetary control system to an institutional effectiveness in Universities, it is therefore a basis for this

study to be conducted to critically examine the relationship between budgeting/budgetary control system and institutional effectiveness in Universities in Kwara State.

\section{CONCEPTUAL FRAMEWORK}

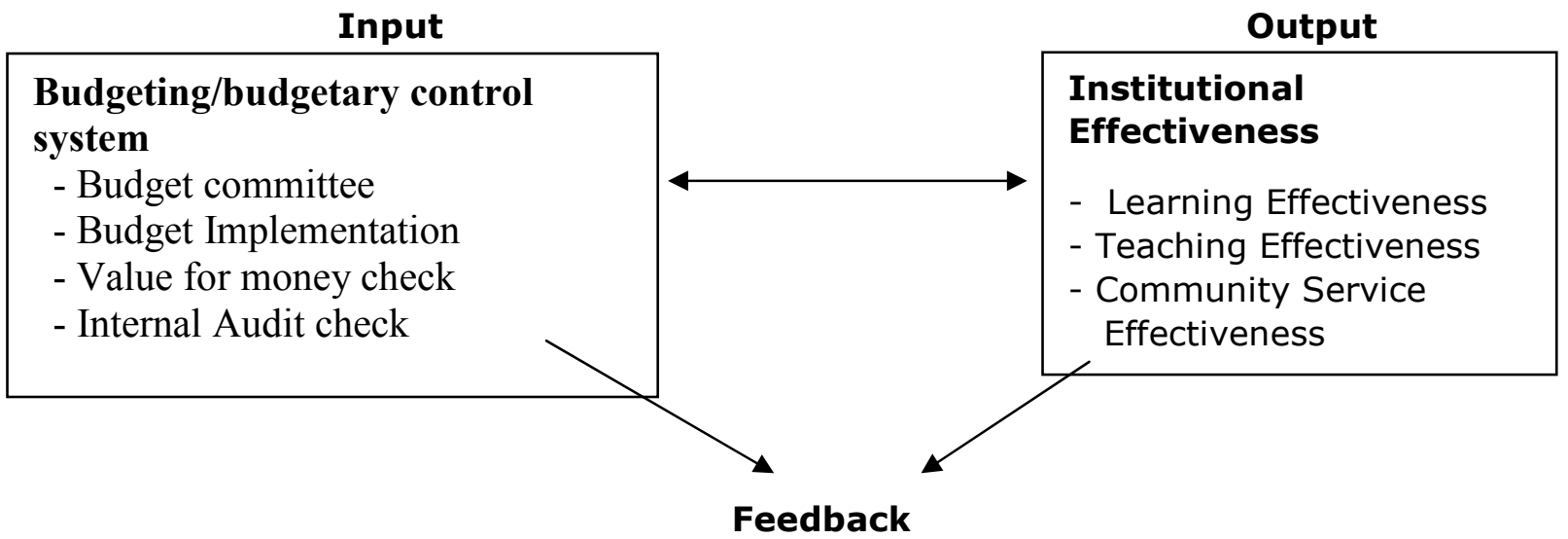

Fig. 1: Conceptual Model on budgeting/budgetary control system on institutional effectiveness.

In fig.1, the framework was designed to examine the relationship that exists between budgeting/budgetary control systems on institutional effectiveness in universities in Kwara State. The budgeting/budgetary control system represents the independent variable of the study while the institutional effectiveness stands for the dependent variable. The budgeting/budgetary control system as an input factor in the system was measured with the sub-variables of budget committee, budget implementation, value for money audit and internal audit check. And the dependent variable of the study that constitutes the output was measured with the sub-variables of learning effectiveness, teaching effectiveness and community service effectiveness. The feedback will monitor the budget performance evaluation in order to guide management decision for the coming budget year.

\section{STATEMENT OF THE PROBLEM}

Budgeting/budgetary control system has been the major financial Volume 1, Number 2 control to check the financial spending in most organizations and institutions. To avoid financial recklessness and spending, several budgetary control mechanisms have to be put in place to check control of money spent in the institutional set up. It is on this regard that many institutions of higher learning in the country have been witnessing misappropriation and embezzlement of funds because of lack of effective internal check on budget spending. The management must lay more emphasis on the institution's budget preparation, monitoring and implementation procedure. Therefore, lack of strict compliance with the budget preparation, monitoring and implementation constitute a problem to this study. However, several studies have been conducted in relation to this study, these are; Egbunike and Unamma (2017) on budgeting, budgetary control and performance evaluation: Evidence from hospitality firms in Nigeria and Omosidi and Abdulkareem (2012), they conducted their study on financial control system \& organizational effectiveness of colleges of legal and Islamic studies in Nigeria. 


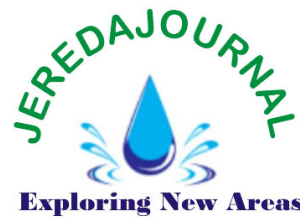

It is also believed that the low morale of top management team in the university system towards an effective preparation of budget and planning, irregular review of the budgetary system, poor understanding of long-term objective within which the budget operates, ineffectiveness of accounting and information system on the part of the personnel pose a major challenge to this study. These are identified problems associated with budgeting and budgetary control system on institutional effectiveness in the universities in Kwara State. These therefore, raised the need to examine the relationship between budgeting/budgetary control system and institutional effectiveness in Universities in Kwara State.

\section{PURPOSE OF THE STUDY}

The main purpose of this study was to examine the relationship between budgeting/budgetary control system and institutional effectiveness in Universities in Kwara State. Other specific purposes were to:

i. examine the impact of budget committee on institutional effectiveness in Universities in Kwara State.

ii. determine the impact of budget implementation on institutional effectiveness in Universities in Kwara State.

iii. examine the impact of value for money check on institutional effectiveness in Universities in Kwara State.

iv. examine the impact of internal audit check on institutional effectiveness in Universities in Kwara State.

v. examine the level of institutional effectiveness in Universities in Kwara State.

\section{RESEARCH QUESTIONS}

For the purpose of this study, the following research questions were raised to guide the study:

i. What is the impact of budgeting/budgetary control system on institutional effectiveness in Universities in Kwara State?

ii. What is the impact of budget committee on institutional effectiveness in Universities in Kwara State?

iii. What is the impact of budget implementation on institutional effectiveness in Universities in Kwara State?

iv. What is the impact of value for money check on institutional effectiveness in Universities in Kwara State?

v. What is the impact of internal audit check on institutional effectiveness in Universities in Kwara State?

vi. What is the level of institutional effectiveness in Universities in Kwara State?

1. There is no significant relationship between budgeting/budgetary control system and institutional effectiveness in Universities in Kwara State.

2. There is no significant relationship between budget committee and institutional effectiveness in Universities in Kwara State.

3. There is no significant relationship between budget implementation system and institutional effectiveness in Universities in Kwara State.

4. There is no significant relationship between value for money check and institutional effectiveness in Universities in Kwara State.

5. There is no significant relationship between internal audit check and institutional effectiveness in Universities in Kwara State

\section{SCOPE OF THE STUDY}

This study covered all the six (6) accredited public and private universities in Kwara State, Nigeria. However, the sampled universities were limited to four universities in the state and this was also limited to the staff of the bursary department of the selected universities. The indicators of budgeting/budgetary

\section{HYPOTHESES}


Journal of Educational Research in Developing Areas (JEREDA

Vol. 1. Issue 2, Pp. 100-111, 2020

http://www.jeredajournal.com

E-mail: info@jeredajournal.com

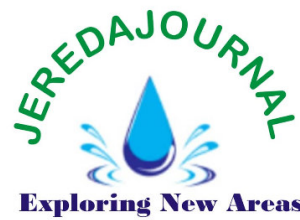

control system were limited to budget committee, budget implementation system, value for money check and internal audit check, while the indicators

\section{METHODOLOGY \\ Research Design}

The study was a descriptive research design of correlation type.

\section{Population and Sample}

The population of the study comprised of all the six (6) accredited universities in Kwara State. The universities are: Kwara State University, Molete; University of Ilorin, Ilorin; AlHikmah University, Adewole, Ilorin; Landmark University, Omu-Aran; Summit University, Offa; and Crown Hill University, Eiyekorin via Ilorin. Simple random sampling technique was adopted to select four universities for the sample, the selected universities represents $67 \%$ of the total population. The sample size of 110 respondents was determined out of the targeted population of 290 staff of the bursary department of the sampled universities using proportional sampling technique because of the differences in their population. The selected sample universities are; Kwara State University, Molete (30); University of Ilorin, Ilorin (30); Al-Hikmah University (25) and Landmark University (25) covering both public and private institutions.

\section{Instrumentation Procedure for Data Collection}

The instrument used for data collection was a researcher-designed questionnaire tagged "Budgeting/Budgetary Control System Questionnaire (BBCSQ)" and

for institutional effectiveness were limited to learning effectiveness, teaching effectiveness and community service effectiveness.

"Institutional Effectiveness Questionnaire (IEQ)".

The questionnaires were based on the four-points likert-type scale, ranging from Strongly Agree (SA)-4, Agree (A)-3, Disagree (D)-2, Strongly Disagree (SD)1 . The instruments were validated by two experts from both Kwara State University, Malete and Ahmadu Bello University, Zaria to ascertain the contents and face validity of the instrument. Cronbach Alpha statistics was used to determine the reliability of the instrument and the reliability coefficient was 0.83 and 0.76 for both instruments. The researcher, with the support from one research assistant personally visited the sampled universities for the administration of the instrument raised for the study.

\section{Method of Data Analysis}

Statistical Package for Social Science (SPSS) version 21.0 was used for coding and analyzing the data collected for the study while descriptive statistics of mean and standard deviation were adopted to answer the research questions raised in the study. The hypotheses raised in the study were tested using Pearson Product Moment Correlation (PPMC) at 0.05 level of significant.

\section{RESULTS}

Research Question 1: What is the impact of budgeting/budgetary control system on institutional effectiveness in Universities in Kwara State?

Table 1: Means and Standard Deviation responses on the impact of budgeting/budgeting control system on institutional effectiveness in Universities in Kwara State.

\begin{tabular}{lccl}
\hline S/N $\quad$ Items & Mean & $\begin{array}{c}\text { Standard } \\
\text { Deviation }\end{array}$ & Impact \\
\hline 1. Budget Committee & 3.48 & .780 & Positive \\
2. Budget Implementation & 3.64 & .782 & Positive \\
3. Value for Money check & 3.34 & .662 & Positive \\
4. Internal Audit check & 3.57 & .736 & Positve \\
\hline
\end{tabular}

Note: Mean Value:(Any value $>2.50$ = Valid (has a positive impact) 
Journal of Educational Research in Developing Areas (JEREDA

Vol. 1. Issue 2, Pp. 100-111, 2020

http://www.jeredajournal.com

E-mail: info@jeredajournal.com

Table 1 shows that the mean values of all the items range from 3.34 to 3.64. This shows that all the items exceed the minimum mean value of 2.50 . This result, however, shows that budgeting/budgetary control system has a positive impact on institutional effectiveness in universities in Kwara State.

Research Question 2: What is the impact of budget committee on institutional effectiveness in Universities in Kwara State?

Table 2: Means and Standard Deviation responses on the impact of budget committee on institutional effectiveness in Universities in Kwara State.

\begin{tabular}{llll}
\hline \multicolumn{1}{c}{ Items } & Mean & $\begin{array}{l}\text { Standard } \\
\text { Deviation }\end{array}$ & Impact \\
\hline 1 Existence of budget committee in the university system & 3.17 & 1.018 & Positive \\
$\begin{array}{l}\text { 2 Budget committee ensures effective budgetary control } \\
\text { in the university system }\end{array}$ & 3.27 & 0.966 & Positive \\
$\begin{array}{l}\text { B Budget approval should be made by the budget } \\
\text { committee considering other parameter }\end{array}$ & & 0.59 & Positive \\
$\begin{array}{l}\text { 4. Budget committee monitoring procedure ensures } \\
\text { quality services delivery in the university system }\end{array}$ & 3.67 & 0.814 & Positive \\
\hline
\end{tabular}

Note: Mean Value:(Any value > 2.50 = Valid (has a positive impact)

Table 2 shows that the mean values of all the items range from 3.17 to 3.67 , that is, they are all above the minimum mean value of 2.50 . This result, however, shows that the existence

Research Question 3: What is the impact of budget implementation on or constitution of budget committee has a positive impact on institutional effectiveness and proper budgetary control guarantees quality services delivery within the universities system.

institutional effectiveness in Universities in Kwara State?

Table 3: Means and Standard Deviations responses on the impact of budgets implementation on institutional effectiveness in Universities in Kwara State.

\begin{tabular}{llccc}
\hline S/N Items & Mean & $\begin{array}{l}\text { Standard } \\
\text { Deviation }\end{array}$ & Impact \\
\hline $\begin{array}{l}\text { 1 Budget implementation procedure has a } \\
\text { significant effect on overall institutional effectiveness }\end{array}$ & 3.51 & 0.896 & Positive \\
$\begin{array}{l}\text { 2. Budget implementation should be monitored and } \\
\text { supervised by a special team within the institution }\end{array}$ & & 0.018 & Positive \\
$\begin{array}{l}\text { 3. Back up documents/receipts should be mandated for all } \\
\text { expenditure incurred }\end{array}$ & 3.59 & 0.782 & Positive \\
\hline
\end{tabular}

Note: Mean Value:(Any value $>2.50$ = Valid (has a positive impact)

All the items in table 3 have positive impact on institutional effectiveness with the mean values ranging from 3.17 to 3.59 . The results indicated that the respondents agreed that the budget implementation procedure in the universities system in Kwara State has a great positive impact on overall effectiveness of the institutions. 
Journal of Educational Research in Developing Areas (JEREDA

Vol. 1. Issue 2, Pp. 100-111, 2020

http://www.jeredajournal.com

E-mail: info@jeredajournal.com

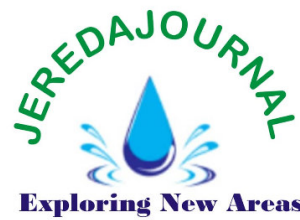

Research Question 4: What is the impact of value for money audit check on

institutional Effectiveness in Universities in Kwara State?

Table 4: Means and Standard Deviations responses on the impact of value for money check on institutional effectiveness in Universities in Kwara State.

\begin{tabular}{|c|c|c|c|}
\hline Items & Mean & $\begin{array}{l}\text { Standard } \\
\text { Deviation }\end{array}$ & Impact \\
\hline $\begin{array}{l}\text { 1. All approved capital expenses should be inspected by } \\
\text { the staff of audit } \& \text { other external bodies }\end{array}$ & 3.59 & 0.782 & Positive \\
\hline $\begin{array}{l}\text { 2. All estimated contract price must be value by an } \\
\text { independent valuer to ascertain its actual }\end{array}$ & 2.89 & 0.999 & Positive \\
\hline $\begin{array}{l}\text { 3. Budgeted expenditure should undergo proper } \\
\text { background check to determine the actual value }\end{array}$ & 3.67 & 0.817 & Positive \\
\hline $\begin{array}{l}\text { 4. Independent valuer should be allowed to carry out } \\
\text { the evaluation of the budget expenditure after completion }\end{array}$ & 2.64 & 0.984 & Positive \\
\hline $\begin{array}{l}\text { 5. Constituting a value for money committee will } \\
\text { help control the budget spending effective }\end{array}$ & 3.59 & 0.782 & Positive \\
\hline
\end{tabular}

Note: Mean Value:(Any value $>2.50$ = Valid (has a positive impact)

In table 4 , the mean values range from 2.64 to 3.67 , meaning that all the items of value for money check have positive impact on institutional effectiveness as revealed in the result because they all exceeded the minimum benchmark value of 2.50 .
Research Question 5: What is the impact of internal audit check on institutional effectiveness in Universities in Kwara State?

Table 5: Means and Standard Deviation responses on the impact of internal audit check on institutional effectiveness in Universities in Kwara State.

\begin{tabular}{|c|c|c|c|}
\hline Items & Mean & $\begin{array}{l}\text { Standard } \\
\text { Deviation }\end{array}$ & Impact \\
\hline $\begin{array}{l}\text { 1. Proper internal check on all the accounting books and } \\
\text { records should be done by internal audit dept }\end{array}$ & 3.67 & 0.814 & Positive \\
\hline $\begin{array}{l}\text { 2. Qualified and experience personnel be engaged in the } \\
\text { internal audit department for proper internal audit check }\end{array}$ & 3.41 & 0.782 & Positive \\
\hline $\begin{array}{l}\text { 3. Source documents should be kept with the internal } \\
\text { audit department for proper checks and verification }\end{array}$ & 3.59 & 0.789 & Positive \\
\hline $\begin{array}{l}\text { 4. Quarterly report of the audit check be prepared by } \\
\text { internal audit for submission to the management. }\end{array}$ & 3.64 & 0.775 & Positive \\
\hline
\end{tabular}

Note: Mean Value: Any value $>2.50$ = Valid (has a positive impact)

The result from table 5 above revealed that the mean value of all the items range from 3.41 to 3.67 . This shows that the items are all valid. This means that the respondents agreed that the internal audit check has a positive impact on institutional effectiveness in universities in Kwara State. 
Journal of Educational Research in Developing Areas (JEREDA

Vol. 1. Issue 2, Pp. 100-111, 2020

http://www.jeredajournal.com

E-mail: info@jeredajournal.com

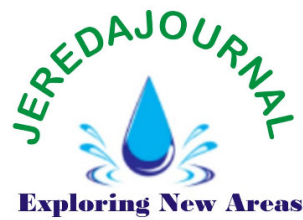

Results of Hypotheses Testing

Table 6: Summary of the Hypotheses Testing

\begin{tabular}{|c|c|c|c|c|c|}
\hline Ho & Relationship & Mean & r-value & $\begin{array}{l}\text { t. } \\
\text { value }\end{array}$ & Decision \\
\hline $\mathrm{HO}$ & $\begin{array}{l}\text { Budgeting/budgetary control system } \\
=>\text { Institutional Effectiveness }\end{array}$ & 36.62 & $.578^{* *}$ & .000 & Rejected \\
\hline $\mathrm{HO}_{1}$ & $\begin{array}{l}\text { Budget Committee = > Institutional } \\
\text { Effectiveness }\end{array}$ & 36.41 & $.307^{* *}$ & .001 & Rejected \\
\hline $\mathrm{H}_{\mathrm{O} 2}$ & $\begin{array}{l}\text { Budget Implementation }=>\text { Institutional } \\
\text { Effectiveness }\end{array}$ & 33.61 & $.546^{* *}$ & .000 & Rejected \\
\hline $\mathrm{H}_{03}$ & $\begin{array}{l}\text { Value for Money Committee }=>\text { Institutional } \\
\text { Effectiveness }\end{array}$ & 13.80 & $.355^{* *}$ & .000 & Rejected \\
\hline $\mathrm{H}_{\mathrm{O} 4}$ & $\begin{array}{l}\text { Internal Audit Committee }=>\text { Institutional } \\
\text { Effectiveness }\end{array}$ & 11.55 & $.371^{* *}$ & .000 & Rejected \\
\hline
\end{tabular}

1. There is no significant relationship between budgeting/budgetary control system and institutional effectiveness in Universities in Kwara State. In table 6 row one, the result of the hypothesis testing revealed that the calculated r-value of .578 is greater than the $t$-value of .000 , hence the hypothesis was rejected. Therefore, there is significant relationship between budgeting/budgetary control system and institutional effectiveness in Universities in Kwara State.

2. There is no significant relationship between budget committee and institutional effectiveness in Universities in Kwara State. In table 6 row two, the result of hypothesis testing revealed that the calculated r-value of .307 is greater than the t-value of .001, hence the hypothesis was rejected. Therefore, there is a significant relationship between budget committee and institutional effectiveness in universities in Kwara State.

3. There is no significant relationship between budget implementation system and institutional effectiveness in Universities in Kwara State. In table 6 row three, the result of the hypothesis testing shows that there is significant relationship between budget implementation system and institutional effectiveness in universities in Kwara State. The result reveals that the calculated r-value of .546 is greater than the $\mathrm{t}$-value of .000, hence the hypothesis was rejected. This implies that significant relationship exists between budget implementation system and institutional effectiveness in universities in Kwara State.

4. There is no significant relationship between value for money check and institutional effectiveness in Universities in Kwara State. In table 6 rows four, the result of the hypothesis testing shows that there is significant relationship between value for money check and institutional effectiveness in Universities in Kwara State (calculated r. value $=.355>\mathrm{t}$. value $=.000$ ), the hypothesis was therefore rejected. Hence, there is a significant relationship between value for money check and institutional effectiveness in Universities in Kwara State.

5. There is no significant relationship between internal audit check and institutional effectiveness in Universities in Kwara State. In table 6 rows five, the result of the hypothesis testing shows that there is significant relationship 
Journal of Educational Research in Developing Areas (JEREDA

Vol. 1. Issue 2, Pp. 100-111, 2020

http://www.jeredajournal.com

E-mail: info@jeredajournal.com

between internal audit check and institutional effectiveness in Universities in Kwara State (calculated r. value $=.371>\mathrm{t}$. value $=.000)$, the hypothesis was

\section{DISCUSSIONS}

In the main hypothesis, analysis revealed that there was a significant relationship between budgeting/ budgetary control system and institutional effectiveness in Universities in Kwara State. This means that budgets preparation and effecting proper budgetary control system in the university environment will positively enhance the institutional effectiveness.

Hypothesis testing one revealed that there was a significant relationship between budget committee and institutional effectiveness in Universities in Kwara State. This implies that having a constituted budget committee in the university system will enhance the institutional effectiveness. This however, means that the budget committee members will ensure that the institutional budget is prepared and relevant procedures are followed for the inclusion of all revenue and expenditure items before the approval. This finding was corroborated by Mora and Bueno (2017). In their study, the result revealed that budget performance reports are prepared regularly and also the budget deviations are reported to the budget committee/top management. Also, Omosidi, et al (2019) affirmed that budget committee is a formalized structure that prepares and monitors budget plans of any organization.

In hypothesis two, the result of the analysis showed that there was significant relationship between budget implementation system and institutional effectiveness in University in Kwara State. The result further revealed that the adherence to and full compliance with all the budget items as stated in the final approved budget is in line with the budget procedures. The finding was in agreement with the result revealed by Omosidi, et al (2019) in their study on budget implementation strategies and organizational effectiveness in Colleges of

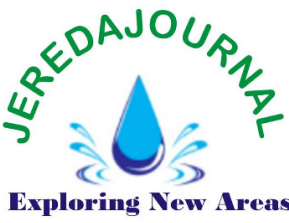

rejected. Therefore, there is a significant relationship between internal audit check and institutional effectiveness in Universities in Kwara State.

Education in Nigeria. The study further revealed that budgeting is a reflection of the degree to which the authorities attach much significance to the funding of the colleges in Nigeria.

In hypothesis three, the result of the analysis revealed that there was a significant relationship between value for money check and institutional effectiveness in Universities in Kwara State. This implies that there should be a stand-by committee on value for money check in the universities to ensure that all the budgeted items are strictly monitored and the real current market value of the items are ascertained and verified to complement the budget item implementation. This process ensures budget compliance and implementation to enhance institutional effectiveness. This was supported by Egbunike and Unamma (2017) in their study on budgeting, budgetary control and performance evaluation: evidence from hospitality firms in Nigeria. Their study revealed that budgeting and budgetary control could serve as an avenue through which organizations in Nigeria could be evaluated and ensure proper monitoring towards compliance with the budgeting processing.

In hypothesis four, the result of the analysis revealed that there was a significant relationship between internal audit check and institutional effectiveness in Universities in Kwara State. This implies that the internal audit of each of the institution has a major role in the examination of the financial procedures of the institution to prevent any mismanagement or misappropriation of fund or even diversion of fund to another expenditure head(s). This process ensures an effective budgetary control system which in turn transforms into an institutional effectiveness. This was supported by Isaac et al. (2015). Their study on a systematic review of budgeting and budgetary control in 
Journal of Educational Research in Developing Areas (JEREDA

Vol. 1. Issue 2, Pp. 100-111, 2020

http://www.jeredajournal.com

E-mail: info@jeredajournal.com

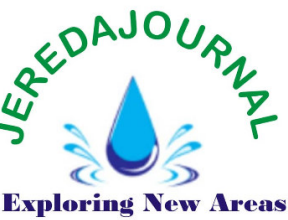

Government owned organizations revealed that inadequate planning by budget committee and internal audit/budget officers is mostly responsible for discrepancies and variance in budget performance.

\section{CONCLUSION}

For effective budgeting/budgetary control to be achieved, programmes and activities should be the basis for allocation of financial resources in the universities. Therefore, the study was conducted to examine the impact of budgeting/budgetary control system on institutional effectiveness in Universities in Kwara State and to actually determine if there is any significant relationship between budgeting/budgetary control system and institutional effectiveness. The findings of the study revealed that all the sub-variables of budgeting/budgetary control system have a positive impact on institutional effectiveness in the sampled universities. However, the institutional goals can be achieved by putting in place a proper financial planning and budgeting/budgetary control within a specific period of time and this should be subjected to proper monitoring and evaluation at the end of each budget year. It was therefore concluded that effective budgeting and budgetary control in the universities system will enhance the institution effectiveness in several ways. This could thereby lead to reduction in cost and eventual increase in revenue surplus among others.

\section{RECOMMENDATIONS}

Based on the findings and conclusion reached on the study, it was recommended that:

1. The majority of budget committee members should be experienced and well versatile in the field of accounting and finance in order to enhance their performance and overall effectiveness in the university system.

2. The university management should lay more emphasis on budget preparation, monitoring and implementation procedure to ensure effective service delivery

and thereby enhance the institutional effectiveness.

3. Training and retraining of bursary and internal audit staff in the university should be encouraged so as to enhance their efficiency and enhance the institutional effectiveness.

4. The management team of the institution should ensure effective internal audit check on budget spending in order to avoid and/or limit the financial mismanagement and recklessness within the system.

5. The funds allocated for capital project should be properly monitored to ensure justification for value for money spending and avoid diversion of fund to ensure institutional objectives are accomplished.

\section{Conflict of Interest}

The authors declare no conflict of interest.

\section{Notes on Authors:}

Shuaib, Folorunsho Muhammed is currently a staff of the bursary department, Kwara State University; a Ph.D student at the Department of Educational Administration \& Planning, Ahmadu Bello University, Zaria. He is a member of the Nigerian Association for Educational Administration and Planning (NAEAP) with registration No: 01613. He is into research on educational planning.

Olanrewaju, Anifat Odunola is an Administrative staff of Air Force Institute of Technology, Kaduna, she is currently running a Ph.D programme at the Department of Educational Administration \& Planning, Ahmadu Bello University, Zaria. She is also a member of the Teachers' Registration Council of Nigeria (TRCN). She is into research on Educational Administration and Planning.

\section{Authorship and Level of Contributions \\ Shuaib, Folorunsho Muhammed partook in the write up of the introduction, statement of the problem, purpose of the study, research questions, formulation of hypotheses and the}


methodology adopted and development of instrument used for the study, administration and validation of the instrument.

Olanrewaju, Anifat Odunola did the analysis, testing of the hypothesis, generate the results and interpretation. And finally, came up with the conclusion and the recommendations for the study. The validation of the instrument was also done.

\section{Disclaimer Statement}

I hereby declare that this paper is a developed research problem. This work has not been submitted to any other examination authority. All texts either quoted directly or paraphrased have been indicated by in-text citations. Full bibliographic details are given in the reference list.

\section{REFERENCES}

Abdullahi, A. M. \& Angus, O. U. (2012). Budget in Nigeria public sector: Need for balanced scorecard perspective. International Journal of Finance and Accounting, 1(2), 1-6.

Anohene, J. (2011). Budgeting and budgetary control as management tools for enhancing financial management in local government authorities, Afigya, Kwabre District Assembly as a case study. A M.Sc thesis submitted to the Institute of Distance Learning, Kwame Nkrumah University of Science and Technology. Ghana.

Chukwuma, O. (2013). Budget preparation and implementation in the Nigerian public sector. Research Journal of Finance and Accounting, $4(16), 50-54$.

Chartered Institute of Management Accountants (CIMA) (2008). Budgeting. Gateway Series.

Egbunike, P. A. \& Unamma, A. N. (2017). Budgeting, budgetary control and performance evaluation: Evidence from hospitality firms in Nigeria. Studies and Scientific Researches Economic Education, 26, 23-31.

Isaac, L., Lawal, M. \& Okoli, T. (2015). A systematic review of budgeting and budgetary control in government owned organizations. Research Journal of Finance and Accounting, $6(6), 1-10$.

Lambe, I. (2014). Appraising the Impact of Budgeting and Planning on the performance of Financial Institutions in Nigeria. Research Journal of Finance and Accounting,5 (16),1216.

Malgwi, A. A. \& Unegbu, A. O. (2012). Budget in Nigerian public sector: Need for balanced scorecard perspective. International Journal of Finance and Accounting,1(2),1-6.

Mora, R. D. \& Bueno, D. C. (2017). Budgetary control process towards improved service delivery among catholic higher educational institutions: A cross-sectional analysis. Arts, Social Sciences, Humanities \& Interdisciplinary Studies (ASSHIS-17), 1-7.

Olaoye, F. O. \& Ogunmakin, A. A. (2014). Budgetary control and performance in public corporations in Osun state. IOSR Journal of Humanities and Social Science (IOSR-JHSS), 19 (7), 59-62.

Omosidi, A. S. \& Abdulkareem, A. Y. (2012). Financial control system \& organizational effectiveness of colleges of legal and Islamic studies in Nigeria. International Journal of Educational Management, 10 (1), 919.

Omosidi A. S. \& Oguntunde, D. A. (2016). Relationship between budgeting system, and students' academic achievement in Colleges of Education, Ilorin, Nigeria. Journal of Education, 35, 183- 195.

Omosidi A. S., Oguntunde, D. A., Oluwalola, F. K., \& Ajao, R. L. (2019). Budget implementation strategies and organizational effectiveness in colleges of education in Nigeria. Makerere Journal of Higher Education, 10 (2),119-131.

Warren, C. S., Reeve, J. M. \& Duchac, J. E. (2014). Financial \& managerial accounting. Cengage learning, Ohio, 283. 